\title{
Bambara Language
}

National Cancer Institute

\section{Source}

National Cancer Institute. Bambara Language. NCI Thesaurus. Code C153850.

A variety of the Manding language spoken as the national language of Mali. 